\author{
Eliza Krupińska \\ Uniwersytet Papieski Jana Pawta II w Krakowie \\ ORCID 0000-0002-1132-1817
}

\title{
Przestrzeń ducha w muzyce: koncepcja podmiotu Eero Tarastiego jako narzędzie interpretacji zjawiska
}

Muzykę od ducha dzieli wyłącznie tęsknota ${ }^{1}$ - pisał Hans Urs von Baltashar, ale sama chęć uczynienia z muzyki kapłanki tego, co transcendentne, była już cały wiek przed Balthasarem żarliwym pragnieniem i deklaracją filozofów. Postmodernistyczny umysł trudno zadowolić zmurszałą estetyką uczucia (Edward Hanslick), poruszającą się wprawdzie z beletrystycznym powabem, ale jedynie w sferze przybliżeń i metafor. Muzyka rozumiana jako forma symboliczna domaga się innych narzędzi, jeżeli celem badacza jest dotknąć choćby kawałka tego, co nazywamy ideą pozamuzyczną; kawałka tego, co nazwalibyśmy tutaj przestrzenią ducha.

Jeżeli znak to „coš”, co komuś zastępuje coś innego pod pew n y m w z gl ęd e $\mathrm{m}$ - jak twierdził Charles $S$. Peirce ${ }^{2}-$ to z góry wykluczyć można, by muzyka jak lustro odbijała z całą dokładnością duchową przestrzeń. Zaczynamy w tym miejscu od uwagi dosyć ogólnej, która na pozór wydaje się oczywista. Uwaga ta jednak zabezpiecza refleksję przed zbyt dosłownym przypisywaniem rzeczywistości muzycznej treści pozamuzycznych. Poza tym warto wciąż podkreślać, że każde dzieło sztuki funkcjonuje w kulturowym kontekście, i to w nim opalizuje znaczeniowo.

Czy są zatem narzędzia, które mogłyby uchwycić fenomen zwany t r a n s ce nd e n t n y m wymiarem muzyki? Strukturalny nurt semiotyki wyrugował znaczenie pozamuzycznej resp. niemuzycznej natury, otaczając szklanym kloszem tzw. poziom neutralny (niveau neutre) - według terminologii zaproponowanej przez Jean’a Molino ${ }^{3}$. Problem „znaczenia w muzyce” został wtedy sprowadzony przede wszystkim do relacji między jednostkami muzycznej struktury, wydzielonymi na drodze

1 H. U. von Balthasar, Rozwój idei muzycznej, w: H. U. von Balthasar, Pisma wybrane, t. 2, przekł. M. Urban CSsR, Kraków 2007, s. 53.

2 Ch. S. Peirce, Collected Papers (2.228), za: H. Buczyńska-Garewicz, Semiotyka Peirce’a, Warszawa 1994, s. 43-44. Por. J. Pelc, Wstęp do semiotyki, Warszawa 1984, s. 14.

3 J. Molino, Fait musical et sémiologie de la musique, „Musique en jeu” 1975 num. 17, s. $37-62$. 
zastosowania procedury segmentacji zainspirowanej metodologią amerykańskiego lingwistycznego dystrybucjonizmu (Zellig S. Harris) ${ }^{4}$. Nie przypuszczamy, by twórcy semiotycznej analizy taksonomicznej, Nicolas Ruwet i Jean-Jacques Nattiez, czerpali wówczas przyjemność ze słuchania Syrinx czy Pelléasa wyłącznie dzięki rozumieniu związków paradygmatyczno-syntagmatycznych obecnych w strukturze dzieła Claude'a Debussy'ego. Poziomy aisthesis i poiesis czekały spokojnie na swoją kolei i obiecujące narzędzia badawcze, jednak neopozytywistyczne nachylenie semiotyki muzycznej w latach 60 . i 70. nie pomagało, ale też nie obiecywało zbyt wiele. Semiotykom strukturalnym pozostały wtedy na otuchę jedynie cytowane przez Nattieza słowa Louisa Hjelmsleva o badaczu, dla którego nie ma nic piękniejszego niż nauka, którą trzeba stworzyćs.

Sytuacja zmieniła się wraz z pojawieniem się koncepcji, które identyfikuje się z semiotyką referencyjną. „Zwrot semantyczny” " polegał w gruncie rzeczy na zmianie paradygmatu. Oparty na sygnifikacji (relacja znaku i znaczenia) model znaku Ferdinanda de Saussure’a zastąpiono znakiem Charlesa S. Peirce’a uwzględniającym zarówno sygnifikację, jak i referencję (relacja znaku i przedmiotu bezpośredniego $)^{7}$. Ten ostatni miał zdecydowaną przewagę nad pierwszym, biorąc pod uwagę specyfikę dzieła muzycznego. Mówiąc wprost, tak jak strukturaliści koncentrowali swoją uwagę na analitycznie „wypreparowanym” ze struktury dzieła muzycznego znaku (utożsamiając strukturę z partyturą jako punktem wyjścia dla analizy taksonomicznej), tak semiotyka Peirce'a eksponowała sam proces nadawania znaczenia. Ten ostatni był rozumiany jako akt dynamiczny ze strony podmiotu; tak samo dynamiczny, jak dynamiczna jest rzeczywistość muzyki czy sztuki w ogóle. Jeżeli chce się wyjść poza jedynie metaforyczny opis tego, co transcendentne czy duchowe w muzyce, jeżeli interesuje nas odpowiedź na pytanie, jak i dlaczego są

4 Ścisłe związki lingwistyki i muzykologii w ramach semiotyki strukturalnej przejawiały się w zastosowaniu mutatis mutandis metodologii i aparatu pojęciowego językoznawstwa przede wszystkim w obszarze analizy muzycznej. By wymienić najważniejsze pojęcia i „hasła kluczowe”: struktura i binarny model znaku, związki paradygmatyczne i syntagmatyczne (de Saussure); fonem, opozycje binarne, cechy dystynktywne; semioza introwersyjna, zasada ekwiwalencji (Koło Praskie; badania Romana Jakobsona i Nikołaja Trubieckiego); segmentacyjne procedury sterowane kategoriami repetycji i transformacji (Zellig S. Harris); analityczno-dedukcyjny model językoznawstwa (Louis Hjelmslev) i wiele innych.

5 Zob. J.-J. Nattiez, Fondements d'une sémiologie de la musique, Paris 1975, s. 9.

6 Por. M. Spitzer, The Sense of Music: Semiotic Essays by Raymond Monelle, „Music \& Letters” 83 (Aug., 2002) no. 3, s. 506.

7 Zapowiedź zmiany paradygmatu była już widoczna w pracach Nattieza, który koncentrował się na pojęciu interpretanta i dynamicznej semiozy, dążąc tym samym do wyjścia poza binarny Saussure'owski model znaku. 
generowane takie, a nie inne znaczenia, niechybnie uwaga nasza skieruje się w stronę semiotyki referencyjnej i jej narzędzi. Interesującą propozycją, która mogłaby przybliżyć problem duchowej przestrzeni, jest koncepcja podmiotu Eero Tarastiego.

By dobrze zrozumieć styl myślenia o dziele muzycznym, taki, jaki proponuje Tarasti, trzeba najpierw zrekonstruować rzeczywistość znakową, w której rozpatrzymy fenomen transcendencji muzycznej. Mowa tu o tle refleksji, które trzeba znać, by uniknąć ewentualnego proton pseudos w rozumieniu kolejnych idei. Dwa komponenty tego tła są wyjątkowo istotne. Wspomnieliśmy już Peirce’a. Przypomnijmy, że jego model znaku obejmuje trzy komponenty: podstawę znaku, przedmiot bezpośredni i interpretanta, który wiąże związkiem reprezentacji dwa pierwsze. Wszystkie komponenty - same będące również znakami - są tym, czym są wyłącznie w relacji triadycznej, i poza nią nie ma o nich jako takich mowy. Jeżeli teraz wyobrazimy sobie, że każdy interpretant ma swojego interpretanta, to generowany jest nieskończony ciąg interpretantów, zwany przez Peirce’a semiozą. Semioza doskonale oddaje doświadczenie muzyczne, w którym istota interpretanta pozostaje funkcją kontekstu, okoliczności i zapewne tysiąca innych zmiennych determinujących taki, a nie inny odbiór dzieła.

Drugim komponentem semiotyki egzystencjalnej, w ramach której Tarasti formułuje koncepcję podmiotu, jest semantyka strukturalna Algirdasa J. Greimasa. $\mathrm{Na}$ lingwistykę Greimasa składa się wiele różnych idei, natomiast w kontekście propozycji Tarastiego warto wspomnieć, że kluczowa w myśli językoznawcy jest sieć relacji, w jakiej rodzi się znaczenie i sam proces nadawania znaczenia ${ }^{8}$. Tutaj zbliżamy się do najważniejszego dla nas problemu. Dla Greimasa nie ma podmiotu, który funkcjonuje na zewnątrz dyskursu. Podmiot jest wytworzony przez dyskurs i jest rozumiany jako wirtualna osoba. Kategorie semiotyczne funkcjonują wewnątrz procesu percepcji i są podobne do Kantowskich kategorii poznawczych jak zauważa Katarzyna Rosner?.

Przechodząc już do samej koncepcji podmiotu, należy podkreślić, że mamy do czynienia z dosyć specyficznym rozumieniem tego, czym jest pod mi ot. Podmiotem może być osoba - posługując się utartym skojarzeniem - ale równie dobrze dzieło muzyczne traktowane lub interpretowane jako żywy organizm. Tarasti czerpie z kilku pozycji filozoficznych. Najważniejsze jest Heglowskie rozróżnienie

8 Semantyka Greimasa obejmuje złożony aparat pojęciowy. By wymienić najbardziej charakterystyczne z pojęć: aktant (byt wytworzony przez strategie dyskursu), modalność (charakteryzuje sytuację aktanta w dyskursie) czy izotopia (rozumiana jako „paralelne warstwy znaczeniowe występujące w obrębie jednego, homogenicznego dyskursu”). Por. J. Lechte, Panorama wspótczesnej myśli humanistycznej. Od strukturalizmu do postmodernizmu, przekł. T. Baszniak, Warszawa 1999, s. 233.

9 K. Rosner, A. J. Greimasa semiotyka narracji, „Pamiętnik Literacki” 67 (1976) nr 2, s. 342. 
bytu w sobie (an-sich-sein) i bytu dla siebie (für-sich-sein). Pierwszy ma potencjalny charakter, który podlega aktualizacji tylko przez relacje, w jakie wchodzi z innymi bytami ${ }^{10}$; drugi oznacza byt, który jest świadomy siebie samego ${ }^{11}$. Inne stanowiska filozoficzne, na które powołuje się Tarasti i które dotyczą podobnej dychotomii bytów, reprezentują Søren Kierkegaard, Jean-Paul Sartre i Jacques Fontanille. Ten ostatni dokonał - jak stwierdza Tarasti ${ }^{12}$ - „modernizacji” Heglowskich kategorii, i to właśnie terminologię Fontanille’a zaproponowaną na łamach pracy Soma et séma: Figures du corps $s^{13}$ stosuje Tarasti, formułując koncepcję podmiotu.

Nie wdając się tutaj w szczegóły semiotyki korporalnej Fontanille'a, trzeba powiedzieć, że kluczowe są dwie sfery podmiotu, które identyfikuje się z kategoriami Me/Self(fr. MoilSoi) ${ }^{14}$. Aplikując kategorie mutatis mutandis w obszarze muzyki, Tarasti nadaje im osobliwe znaczenia. Me oznacza podmiot - indywidualną jednostkę; $M e$ przejawia egzystencjalny wymiar podmiotu, sprowadzony do zwoju indywidualnych wrażeń, uczuć i doznań (bundle of sensations ${ }^{15}$ ); Self przejawia z kolei społeczny i wspólnotowy wymiar podmiotu, który jawi się taki, jaki jest postrzegany przez innych. Me i Selfkonstytuują jednię, którą Tarasti określa zapożyczonym od biosemiotyka Jakoba von Uexkülla terminem Ich-Ton - eksponującym tożsamość i indywidualność organizmu. W przypadku muzyki Tarasti mówi o Ich-Ton kompozytora i/lub jego dzieła ${ }^{16}$.

Lecz nie byłoby semiotyki egzystencjalnej bez fundamentalnego pytania o Innego (L'Autre/Other). Co by było, gdyby „świat” Ich-Ton (złożony ze sfer Me i Self) zderzyć ze „światem” Innego (Dich-Ton)? Zakładając, że Ich-Ton i Inny nawiązują komunikację, ta ostatnia wynika - zdaniem badacza - ze wspólnego kodu kulturowego. Sfery Self obydwu „organizmów” posiadają wspólną przestrzeń znakową, jak dwa nakładające się na siebie częściowo zbiory. Oznacza to, że komunikacja dwóch bytów opiera się na społecznie ustanowionym, semiotycznym kodzie.

10 E. Tarasti, Introduction to a philosophy of music, w: Music and the Arts: Proceedings from ICMS 7, ed. by E. Tarasti, Helsinki 2006, s. 16 (Acta Semiotica Fennica, 23. Approaches to Musical Semiotics, 10).

11 Jak pisze Tarasti: „When a person becomes for himself what he is in himself, then he usually recognizes his identity: in semiotic terms, he becomes meaningful to himself" (E. Tarasti, Introduction to a philosophy of music, dz. cyt., s. 16).

12 Zob. E. Tarasti, Introduction to a philosophy of music, dz. cyt., s. 17.

13 J. Fontanille, Soma et séma: Figures du corps, Paris 2005.

14 Zachowujemy terminologię w oryginalnej wersji, ponieważ przekład na j. polski terminów moi (me) i soi (self) zasadniczo nie wniósłby nic, co ułatwiłoby zrozumienie wykładanych tu założeń koncepcji podmiotu. Ponadto, oryginalna - francuska i angielska wersja terminów (takie podaje Tarasti) zdaje się być bardziej sugestywna i lepiej oddawać sens wykładanych idei.

15 Zob. E. Tarasti, Introduction to a philosophy of music, dz. cyt., s. 18.

16 Zob. E. Tarasti, Introduction to a philosophy of music, dz. cyt., s. 18. 
Mimo że Tarasti w dalszych etapach dokonuje przetasowań w swojej propozycjim.in. syntetyzując kategorie Fontanille'a z kategoriami Heglowskimi i przypisując im modalności - my poprzestaniemy na tym etapie. Potrzebny nam jest bowiem sam model podmiotu i komunikacji między dwiema znakowymi rzeczywistościami. Odróżnienie „ja egzystencjalnego” od ,ja społecznego” oraz istnienie kulturowego kodu może z dużym powodzeniem objaśniać wiele faktów wiążących muzykę i przestrzeń pozamuzyczną. Należy przypomnieć, że naszą uwagę zwraca jednak specyficzny typ znaczenia pozamuzycznego, który możemy nazwać „przestrzenią ducha”, a ta nasuwa skojarzenia z metafizyką i teologią - by ująć problem dosyć ogólnie.

Rozpatrzmy teraz kilka przypadków. Johann B. Vanhal, zagorzały chrześcijanin - jak nazywała go wiedeńska arystokracja, jest autorem nie kilku, lecz kilkudziesięciu mszy. Nie byłoby w tym nic dziwnego, gdyby nie fakt, że w całym swoim życiu Vanhal nigdy nie objął posady muzyka kościelnego. Self kompozytora wyraża praktykę konwencjonalnego gatunku w jego czasach, ale to $M e$ wyraża przez jego dzieło sakralne solidarność z religijną wspólnotą. Co innego Franz Schubert, którego egzystencjalne $M e$ konsekwentnie w swoich sześciu mszach omija zdanie „Et in unam sanctam ecclesiam catholicam et apostolicam”, by ulepić dźwiękami prywatną duchową posesję pozbawioną instytucji Kościoła. „Był oddanym chrześcijaninem, ale nie wzorowym członkiem Kościoła” - skomentował postawę Schuberta Ernst Gombrich ${ }^{17}$. W każdym z tych przypadków kompozytor konsekwentnie wpisuje w tworzywo muzyki swoje $M e$ będące duchową, intymną wypowiedzią.

Sięgając do innej przestrzeni ducha, wiążącej mistykę, filozofię i religię, mamy przypadek Jana Sebastiana Bacha i Aleksandra Skriabina. Oprócz Self Bacha wyrażonego doskonałością warsztatu, przemawia przez jego dzieło numerologiczne $\mathrm{Me}$ wyrażone przez praktykę gematrii i symbolikę teologiczną. Jakkolwiek numerologia w twórczości Bacha była od czasów badań Friedricha Smenda przedmiotem kontrowersji, to interpretacja jej w zrekonstruowanym kontekście kulturowym przemawia za uznaniem zjawiska jako występującego i wpisującego się w sferę indywidualnego i egzystencjalnego Me kompozytora i/lub jego dzieła ${ }^{18}$.

Ezoteryczny wymiar twórczości Skriabina jest kolejnym przykładem eksponowania $M e$ na tle wyrażonego monumentalną, późnoromantyczną symfoniką Self. Idea muzycznego Misterium, którą Skriabin zamierzał zrealizować pod koniec życia,

17 E. H. Gombrich, Pisma o sztuce i kulturze, Kraków 2011, s. 562.

18 Do rekonstruowanego kontekstu należałaby z pewnością m.in. idea uniwersalnego języka sformułowana przez Gottfrieda Leibniza w De arte combinatoria (1666); opublikowany w formie traktatu przez Christiana F. Hunolda w 1707 roku wykład Erdmanna Neumeistra dotyczący retorycznych loci topici (uwagę zwraca przede wszystkim pojęcie locus notationis artificium cabalae) oraz poglądy estetyczno-muzyczne Lorenza Ch. Mizlera von Kolof zawarte w czasopiśmie „Neu eröffnete musikalische Bibliothek”. 
pozostawała pod silnym wpływem m.in. teozofii Heleny Bławatskiej oraz poglądów filozoficznych Władimira Sołowjowa i Wiaczesława Iwanowa. W zamyśle Skriabina Misterium - kosmiczny, globalny akt wiodący do przeistoczenia całej ludzkości miało reprezentować symbolicznie trzy procesy: kosmogenezę (ewolucję wszechświata), antropogenezę (rozwój rasy ludzkiej) oraz historię rozwoju ludzkiego ducha ${ }^{19}$. Bardzo złożony estetyczny program wpisany w dzieło Skriabina wyraźnie odcina jego egzystencjalne $M e$ od Self. Rozumienie treści duchowej, jaką zawiera chociażby pozostawiony przez Skriabina L'Acte Préalable do Misterium, obejmuje kilka pojęć. Pojęcie „teurgii” zakładające iluminację świata za pomocą sztuki i piękna oraz tzw. sobornos - zjednoczenie ludzkości pod postacią panhumanistycznego organizmu; jak również teozoficzne przekonanie o konieczności połączenia świata materialnego z duchowym oraz wiara w braterstwo wszystkich religiii ${ }^{20}$ - to tylko najważniejsze elementy z bardzo rozbudowanej treści duchowej, jaką Skriabin planował pozostawić ludzkości w artystycznym testamencie.

Ale intencja kompozytora to jedno, a efekt na poziomie aisthesis to drugie. Gdy w ostatnim akcie opery Jules'a Masseneta Thaïs umiera w mistycznym uniesieniu, powraca temat Medytacji. Dla odbiorcy staje się jasne, że słyszy motyw duchowej przemiany bohaterki. Sprzężenie motywu i sytuacji działa na dobrze znanej zasadzie idée fixe, czyli w tym wypadku przypisaniu danej sekwencji melodycznej do określonej sytuacji. Odczytanie idei Medytacji staje się możliwe dzięki Self: konwencji, która stanowi fundament symbolu - powołując się na definicję symbolu Peirce’a. Weźmy również pod uwagę warstwę tekstową. Thaïs ma wizję raju i precyzyjnie ją przedstawia Atanaelowi: róże, które nigdy nie blakną; orszak uśmiechniętych aniołów, proroków i świętych z naręczem kwiatów; dwóch serafinów o białych skrzydłach; dźwięki harf; unosząca się słodka woń i wreszcie... Twarz Boga. Odbiorca posługujący się kodem kulturowym Self-tym samym, którego użył librecista - bez chwili namysłu skojarzy słowa bohaterki z wizją raju. Ikonograficzne przedstawienie raju, utrwalone kulturowo m.in. dzięki Dantemu (Boska komedia) ${ }^{21}$, bez wątpienia jest czytelną pozamuzyczną ideą, o ile odbiorca funkcjonuje w tym samym kulturowym kręgu, co dzieło.

Konwencjonalne Self staje się wyjaśnieniem również takich sytuacji, w których sprawdza się teoria warunkowania Johna B. Daviesa nazwana przez psychologa „Darling, they’re playing our tune” („Kochanie grają naszą melodię”) 22.

19 Por. V. Kravchenko, The symbolic structure of Alexander Scriabin's „Mystery”, w: Music and the Arts: Proceedings from ICMS 7, vol. 2, dz. cyt., s. 712-713.

20 Por. V. Kravchenko, The symbolic structure of Alexander Scriabin's „Mystery”, dz. cyt., s. 716.

21 Por. E. Fubini, Historia estetyki muzycznej, Kraków 2002, s. 107-108.

22 J. B. Davies, The psychology of music, London 1978, passim. 
Teoria opisuje często występujące zjawisko polegające na trwałym przypisaniu do konkretnego utworu muzycznego skojarzeń i emocji, pod wpływem pierwotnych okoliczności, w jakich utwór ten został wysłuchany. Aby zrozumieć teorię Daviesa wystarczy mieć w uszach Ave Maria Bacha-Gounoda (lub Schuberta - jak kto woli), a z dużym prawdopodobieństwem uwarunkowane zwyczajem społecznym skojarzenie ślubnego sakramentu wyda nam się oczywistością. Zderzenie Ich-Ton z Innym poskutkuje nie tylko wspólną płaszczyzną Self(konwencja ceremonii ślubnej), ale być może pociągnie płaszczyznę $M e$, gdy odniesienie dotknie osobistego doświadczenia życiowego.

Ciekawym przypadkiem będzie korespondencja Martina Heideggera i Hannah Arendt. Na uwagę zasługuje epistolarny zwyczaj Heideggera polegający na umieszczeniu w nagłówku listu tytułu dzieła muzycznego. Na początku listu pisanego z Fryburga 12 kwietnia 1950 roku widnieje: Beethoven, opus 111. Adagio, finat. Na końcu zaś autor pisze: „A teraz, Hannah, na dodatek i z dobrym słowem podarowałaś jeszcze opus 111 Beethovena. Jego dźwięk już zbratał się z owym blaskiem, o którym mówiłem na początku tego listu" ${ }^{23}$. Metaforyczny podarunek w postaci wolnego ogniwa sonaty Ludwiga van Beethovena wpisuje się zatem w aurę listu i kierowanych do Arendt słów. Blask, o którym pisze filozof, to tylko słowo-klucz otwierające afirmację miłości: „(...) Nie umiem tego nazwać. Ale jest to to, co miłujące w owej miłości, która rzuciła swój blask do mojej pracowni, gdy Elfride i Ty trzymałyście się w ramionach (...)”. I dalej: „Przy tym wszystkim często nie mogę się powstrzymać od myśli o słowach Augustyna, które z pewnością znasz: Nulla est enim maior ad amorem invitatio, quam prevenire amando [„Nie ma większego zaproszenia do miłości niż miłować" - tł. E. K.]"24. Adagio z sonaty Beethovena najwyraźniej stanowiło pozamuzyczną ideę, która zdaniem Heideggera dopełniała metafizyczny kontekst listu. Połączenie Ich-Ton i Innego (osobistej sytuacji i skojarzenia jej z ekspresją sonaty Beethovena) nastąpiło dzięki wspólnej znakowej przestrzeni Self, w której egzystencjalne $M e$ mogło znaleźć właściwy wyraz ${ }^{25}$.

W obszar refleksji metafizycznych ucieka również Artur Rubinstein w filmie autobiograficznym L'amour de la vie ${ }^{26}$. Przejmująca jest scena, w której pianista kładzie dłonie na klawiaturze i wykonuje a vista fragment transkrypcji Adagio z I Kwartetu z op. 59 Beethovena. Wybór akurat tego fragmentu nie wydaje się

23 H. Arendt, M. Heidegger, Korespondencja z lat 1925-1975, przekł. S. Lisiecka, Warszawa 2010, s. 80 .

24 H. Arendt, M. Heidegger, Korespondencja z lat 1925-1975, dz. cyt., s. 78.

25 Wyjaśniając problem dokładnie od strony semiotycznej, pomocne mogłoby się okazać pojęcie interpretanta emocjonalnego, o którym pisze Peirce, podając przykład muzyki i jej oddziaływania. Zob. Ch. S. Peirce, Collected Papers (5.475), dz. cyt., s. 80.

26 L'amour de la vie, reż. F. Reichenbach, G. Patris, 1969. 
przypadkiem, gdy Rubinstein porównuje muzykę do miłości, tajemniczego świata, a nade wszystko duszy, którą trudno zdefiniować, ale która może być siłą człowieka, ludzi i fundamentem wszelkiej twórczości - jak twierdzi. Korespondencję dwóch rzeczywistości znakowych, tj. Adagio Beethovena (Ich-Ton) i przestrzeni ducha (Inny), o której myśli Rubinstein, tłumaczy częściowa wspólnota obszarów Self. Teoria podmiotu jeszcze raz objaśnia mechanizm kojarzenia „tekstów kulturowych" i ich łączenia, jak ogniw w łańcuchu.

\section{Postscriptum}

W artykule przedstawiono interpretację faktów wiążących - w dużym uproszczeniu - muzykę i jej transcendentny wymiar. W tym celu posłużyliśmy się jedynie wycinkiem koncepcji podmiotu Tarastiego. Posłużyła nam ona do zinterpretowania intencji kompozytora i idei, które znalazły artykulację w jego dziele, jak również wrażeń, doznań i sposobu rozumienia muzyki od strony odbiorcy czy wykonawcy. Należy jednak podkreślić, że grupowanie faktów podług wyodrębnionych poziomów czy to twórczości, czy to odbioru, czy w końcu samego dzieła - nie ma tutaj wartości ontologicznej (jedynie porządkująca). Dyskurs muzyczny generuje podmiot w jego własnych granicach, dlatego należy stawiać pytanie nie o to, kto czuje transcendentny wymiar muzyki (kompozytor, słuchacz, wykonawca?); nie o to gdzie kończy się dzieło, a rozpoczyna jego transcendencja, ale jak to się dzieje, że transcendencja muzyki ma i może mieć miejsce. Należy brać pod uwagę również i to, że współcześnie uprawiane nauki o sztuce nie potrzebują już ścisłej i niezawodnej metodologii dającej obietnicę rozwiązania jakichkolwiek zagadek. Dlatego w tym wypadku wolimy mówić raczej o projekcie interpretacyjnym zjawiska muzyki niż o jakiejkolwiek metodologii. Jest to zarówno uczciwe intelektualnie, jak i wierne dyscyplinie semiotyki muzycznej jako nowocześnie praktykowanej muzykologii.

\section{Abstrakt}

Duchowy wymiar muzyki zawsze stanowił zagadkę. W XIX wieku próbowano rozpaczliwie uchwycić ducha muzyki, uciekając w sferę metafor i eseistyki z jednej strony, a sięgając po filozoficzne narzędzia z drugiej. Estetyka uczucia stała się jednak w pewnym momencie niewygodna. „Niewyrażalne” muzyki, stanowiące z początku jej najwyższą cnotę, 
prowadziło nie dalej niż w sferę poetyki, nie wyjaśniając fenomenu muzycznej transcendencji. Lata 60. i 70. XX wieku przyniosły narzędzia strukturalnej semiotyki muzycznej. Ta ostatnia mimo neopozytywistycznej, laboratoryjnej dokładności stroniła od problemu znaczenia treści pozamuzycznych, ograniczając swoje badania do poziomu neutralnego i wyrażając wiarę w istnienie obiektywnego tekstu dzieła. „Zwrot semantyczny” przyniósł nowy odłam semiotyki eksponującej sam proces znaczenia rozumiany jako akt dynamiczny i nierozerwalnie związany z kontekstem kulturowym. W tej właśnie perspektywie semiotycznej proponuje się interpretację fenomenu duchowej treści muzyki, wykorzystując elementy koncepcji podmiotu Eero Tarastiego. Egzystencjalne $M e$ i społeczne Self wyjaśnia wiele idei związanych z treścią pozamuzyczną dzieła (zwłaszcza natury teologicznej i metafizycznej) i przyczynia się do zrozumienia mechanizmu wiązania „tekstów kulturowych” w wiązki znaczeniowe.

Stowa kluczowe: semiotyka; Tarasti; Greimas; muzyka sakralna; podmiot muzyczny; znak; znaczenie; interpretacja; teologia; estetyka

\section{Abstract \\ The space of spirituality in music: the concept of a subject by Eero Tarasti as an instrument for interpreting a phenomenon}

The spiritual dimension of music has always been shrouded in a mystery. In $19^{\text {th }} \mathrm{c}$. some desperate attempts were made to capture the spirituality of music by resorting, on the one hand, to the sphere of metaphors and essayism, on the other, to philosophical tools. The aesthetics of emotions, however, began at some point to be uncomfortable. "The inexpressible" of music, be at first its highest virtue, led no farther than to the sphere of poetics without explaining the phenomenon of musical transcendence. The 60 'and the 70 ' of $20^{\text {th }} \mathrm{c}$. brought the instruments of the structural musical semiotics. The latter, despite its neo-positivist and laboratory precision, shunned the significance of extra-musical subject matters, confining its research to some neutral levels and believing in the existence of an objective text of a music work. "The semantic turn" brought a new branch of semiotics exposing the very process of meaning understood as a dynamic act inextricably linked with a cultural context. In this semiotic perspective it is suggested to interpret the phenomenon of spiritual content of music by employing the elements of the concept of a subject defined by Eero Tarasti. The existential $M e$ and the social Self explain many ideas related 
to extra-musical subject matters of a music piece (particularly those of theological and metaphysical nature) helping to understand the mechanism of merging "cultural subject matters" into semantic relationships.

Keywords: semiotics; Tarasti; Greimas; sacred music; musical subject; sign; meaning; interpretation; theology; aesthetics

\section{Bibliografia}

Arendt H., Heidegger M., Korespondencja z lat 1925-1975, przekł. S. Lisiecka, Warszawa 2010.

Balthasar H. U. von, Rozwój idei muzycznej, w: H. U. von Balthasar, Pisma wybrane, t. 2, przekł. M. Urban CSsR, Kraków 2007.

Buczyńska-Garewicz H., Semiotyka Peircéa, Warszawa 1994.

Davies J. B., The psychology of music, London 1978.

Fontanille J., Soma et séma: Figures du corps, Paris 2005.

Fubini E., Historia estetyki muzycznej, Kraków 2002.

Gombrich E. H., Pisma o sztuce i kulturze, Kraków 2011.

Kravchenko V., The symbolic structure of Alexander Scriabin's „Mystery”, w: Music and the Arts: Proceedings from ICMS 7, vol. 2, ed. E. Tarasti, Helsinki 2006, s. 712-722 (Acta Semiotica Fennica, 23. Approaches to Musical Semiotics, 10).

Lechte J., Panorama wspótczesnej myśli humanistycznej. Od strukturalizmu do postmodernizmu, przekł. T. Baszniak, Warszawa 1999.

Molino J., Fait musical et sémiologie de la musique, „Musique en jeu” 1975 num. 17, s. 37-62.

Nattiez J.-J., Fondements d'une sémiologie de la musique, Paris 1975.

Pelc J., Wstęp do semiotyki, Warszawa 1984.

Rosner K., A. J. Greimasa semiotyka narracji, „Pamiętnik Literacki” 67 (1976) nr 2, s. 341352.

Smith T. A., More Evidence of Numeral-Logical Design in Bach's "St. Matthew Passion”, „Bach” 17 (April, 1986) no. 2, s. 24-30.

Spitzer M., The Sense of Music: Semiotic Essays by Raymond Monelle, „Music \& Letters” 83 (Aug., 2002) no. 3, s. 506-509.

Tarasti E., Introduction to a philosophy of music, w: Music and the Arts: Proceedings from ICMS 7, ed. by E. Tarasti, Helsinki 2006 (Acta Semiotica Fennica, 23. Approaches to Musical Semiotics, 10). 